\title{
Acacia trees on the cultural landscapes of the Red Sea Hills
}

\author{
Joseph J. Hobbs • Knut Krzywinski • Gidske L. Andersen • Mohamed Talib • \\ Richard H. Pierce • Ahmed E. M. Saadallah
}

Received: 6 March 2014/Revised: 18 June 2014/ Accepted: 28 June 2014/Published online: 18 July 2014 (C) The Author(s) 2014. This article is published with open access at Springerlink.com

\begin{abstract}
This paper examines interactions between five pastoral nomadic culture groups of the Egyptian and Sudanese Red Sea Hills and the acacia trees Acacia tortilis (Forssk.) Hayne subsp. tortilis and subsp. raddiana growing in their arid environments. A. tortilis is described as a keystone species both ecologically and culturally: the trees play such critical roles in ecosystems and social groups that their removal would greatly impact both systems. Interviews in the field with the Semitic, Arabic-speaking Ma'aza and Ababda, and the Cushitic, Beja, Bidhaawyeet-speaking Bishaari, Amar Ar and Hadandawa nomads probed the cultural and ecological contexts of acacias in pastoral nomadism, revealing deep insight into traditional ecological knowledge and traditional perceptions and uses of the trees. The paper describes how this knowledge guides pastoral decision-making, with
\end{abstract}

Communicated by Danna J Leaman.

\section{J. J. Hobbs}

Department of Geography, University of Missouri, 8 Stewart Hall, Columbia, MO 65211, USA

e-mail: hobbsj@missouri.edu

K. Krzywinski $(\bowtie)$

Department of Biology, University of Bergen, P.O. Box 7800, 5020 Bergen, Norway

e-mail: knut.krzywinski@bio.uib.no

K. Krzywinski · G. L. Andersen

UNI Research Environment, P.O. Box 7810, 5020 Bergen, Norway

G. L. Andersen

e-mail: gidske.andersen@uni.no

M. Talib

Beja Cultural Studies Center, Red Sea University, Main Campus, P.O. Box 23, Port Sudan, Sudan e-mail: talibm37@yahoo.com

R. H. Pierce

Department of Linguistic, Literary and Aesthetic Studies, University of Bergen, Sydnesplassen 7 , 5007 Bergen, Norway

e-mail: richard.pierce@1le.uib.no 
acacias as a particularly critical component of the pastoral livelihood in both normal and stressful circumstances. A. tortilis is the most important reliable vegetation resource for nomads while also providing fuel and other useful products, ecosystem services for people and animals, and increased biodiversity by providing diverse microhabitats and resources for other species. We describe aspects of kinship, territorial organization, spiritual beliefs and tribal law underlying the significance of trees on the cultural landscape. We discuss environmental and economic challenges to human/tree relationships and to pastoral livelihoods. We challenge views of nomads as agents of ecological destruction, and propose maintenance and restoration of traditional pastoralism as viable alternatives in dryland development.

Keywords Acacia tortilis · Eastern Sahara - Pastoral nomadism - Cultural landscape · Cultural keystone species

\author{
Abbreviations \\ RSH Red Sea Hills \\ TEK Traditional ecological knowledge
}

\title{
Introduction
}

This paper examines interactions between five pastoral nomadic culture groups of the Egyptian and Sudanese Red Sea Hills (RSH) and the acacia trees growing in their arid environment. We depict Acacia tortilis (Forssk.) Hayne as a keystone species both ecologically and culturally: the trees play such critical roles in ecosystems and social groups that their removal would greatly impact both systems. Members of the five culture groups are keen observers of environmental and social linkages, and in our interviews cited some of acacia's keystone properties with these words:

"All the living organisms in the desert benefit from acacia. It is like a chain: every organism depends on another one, and you always find acacia on the chain" (Ababda man, age 60+).

"If acacias go, no life will remain on the desert" (Ababda man, age 35-40).

"Nothing is better than green trees. There is no life without these trees." (Hadendowa woman, age 50).

"Without the trees, there are no animals and no Bedouin" (Ma'aza man, age 45).

Here we examine the cultural and ecological contexts of acacias in pastoral nomadism, emphasizing traditional ecological knowledge (TEK) and other traditional knowledge and perceptions of the trees. We see how this knowledge guides decision-making, revealing acacias as a particularly critical component of the pastoral livelihood. We discuss aspects

\author{
A. E. M. Saadallah \\ Egyptian Environmental Affairs Agency (EEAA), Nature Conservation Sector, Southern Sector \\ Protectorates, Regional Branch of Aswan, Elsadat Road, Aswân 81111, Egypt \\ e-mail: ahmed.ebaid@gmx.com
}

Present Address:

A. E. M. Saadallah

Culture and Environment in Africa Master Programme, University of Cologne, Köln, Germany 
of kinship, territorial organization, spiritual beliefs and tribal law that relate directly to the status of trees on the cultural landscape. We discuss how people accommodate variable environmental and economic conditions in ways that affect their relationships with trees. We conclude with perspectives on changes in nomadic knowledge systems, management and livelihood in the region's dryland ecosystems, and on the continued existence and possible restoration of these ecosystems in the future.

However widely it may be viewed as a desert wilderness we see the eastern Saharaincluding our study area of the RSH of eastern Egypt and northeastern Sudan-as a cultural landscape best understood through attention to the dynamics of human-environment interaction and human culture (Krzywinski and Pierce 2001; Reynolds et al. 2007). The geographical concept of cultural landscape denotes a landscape shaped by human culture, in contrast with a primordial "natural landscape" (Schlüter 1907; Sauer 1925; Krzywinski et al. 2009). Today this concept, which is especially relevant to our study, is also relevant to sustainable management of natural resources worldwide:

The term "cultural landscape" embraces a diversity of manifestations of the interaction between humankind and its natural environment. Cultural landscapes often reflect specific techniques of sustainable land-use, considering the characteristics and limits of the natural environment they are established in, and a specific spiritual relation to nature. Protection of cultural landscapes can contribute to modern techniques of sustainable land-use and can maintain or enhance natural values in the landscape. The continued existence of traditional forms of land-use supports biological diversity in many regions of the world. The protection of traditional cultural landscapes is therefore helpful in maintaining biological diversity. (UNESCO 2014)

The cultural landscapes of our study region are significant manifestations of local heritage, shaped over millennia not only by physical resource management practices but also by invisible myths, beliefs and traditions. Practices, perceptions and TEK pass from generation to generation, perpetuating the viability of pastoral nomadism on these cultural landscapes (Krzywinski and Pierce 2001; Krzywinski et al. 2009).

Acacias and all other perennial plants in the study area are shaped by human activities both directly by people and indirectly by their domestic animals. These forces even give the acacia tree its distinctive canopy shape, which upon close scrutiny clearly serves to increase green biomass for fodder and optimize its uses by pastoralists (Krzywinski and Pierce 2001; Andersen et al. 2014). We can adequately interpret and explain acacia shapes and architecture, populations and distributions and many other details on the cultural landscape only by understanding the dynamic interplay of people and biotic as well as abiotic factors within the indigenous land use management systems.

In recent decades there has been increasing attention to TEK and related perspectives, and to their roles in shaping cultural landscapes and human-environment systems (Birks 1988; Reynolds et al. 2007; Berkes 2008). The emerging consensus is that the boundary between traditional and scientific ecological knowledge is soft, and that an integrative science combining the two can be highly productive (IISH 2014; Agrawal 1995; Huntington 2000; Reynolds et al. 2007). TEK in ecosystems governed by slow dynamics, such as in arid lands, is of outstanding scientific interest. Important processes such as regeneration of perennial vegetation normally happen on the scale of a decade or longer (Wiegand et al. 2004). These processes arguably are best understood not by transient outsiders but by people living with and depending on them. In recent decades there has also been growing attention to drylands as human-environment systems, with recognition of the non-equilibrium dynamics of arid ecosystems (Ellis and Swift 1988; Westoby et al. 1989; 
Briske et al. 2003; Vetter 2005; Reynolds et al. 2007). These nuanced, bottom-up approaches that value indigenous knowledge and decision-making contrast with narratives of the 1970s and ' $80 \mathrm{~s}$, when traditional land use practices of nomadic pastoralists were blamed for causing desertification by overexploiting and misusing natural resources in a fragile environment (Lamprey 1983; Thomas and Middleton 1994; Niamir-Fuller 1999; Davis 2005; Herrmann and Hutchinson 2005; Homewood and Randall 2008).

Today such narratives seem ill-conceived as they were often based on prejudice against nomads rather than on sound science, and TEK-informed conservation projects are now widely-advocated. Apparent progress must however be viewed critically. Conservation area managers in many cases cite the balance achieved between nomads and their arid environments in former times, but insist they must now intervene because indigenous knowledge and resource use systems have broken down ("Bedouin knowledge is too important to be left in the hands of the Bedu"; Gilbert 2013, p. 65). Many of these interventions continue to invoke older adages and procedures: Bedouin and other pastoralists do not need to be consulted (instead, they need to be taught how to protect the environment) and cannot be co-managers because their land uses are destructive. Even evidence to the contrary, for example the proliferation of flora in areas grazed by livestock, does not deter the imposition of grazing management plans with zones of livestock exclusion meant to protect natural systems (Chatty 2006; Rowe 2006; Gilbert 2013). The cultural landscape approach, which in the present study illuminates the complex and interrelated cultural and environmental variables at work in the arid ecosystem, is anathema to such ideas and practices.

\section{Methods}

Information discussed here was collected during interviews with 74 desert pastoralists intermittently between August 2010 and March 2013 in the RSH of Egypt and Sudan, complemented by our numerous individual field studies, participant observations and interviews that began in 1980. Our informants included both active and previously active but now settled nomadic pastoralists representing a wide and deep cross section of tribal areas, kinship units, males and females, from children through the elderly. The interviews, in the local languages of Arabic and Bidhaawyeet, were structured, open-ended and conversational, with the subject of trees often imbedded in broader socio-environmental contexts. Women scholars conducted the interviews with women.

All interviews and conversations were recorded digitally with informants' consent. One of our objectives in the field was to capture as much information as possible from our informants, who with few exceptions could not read or write. In addition to their life experiences these people have a huge corpus of inherited lore. Throughout the study area, large numbers of these tribespeople are at various stages of settling down, and in the process are acquiring new knowledge in place of TEK. Because our informants understand acacias within the broader framework of declining TEK, there was an element of urgency in the fieldwork. This article uses verbatim quotes to convey relevant TEK, and help minimize the biases of authors communicating on behalf of the informants.

\section{Environment and people}

The RSH and adjoining plains and plateaus in Egypt and Sudan are a part of the Sahara east of the Nile (Fig. 1). There is a regional south to north moisture gradient, ranging from 
arid in its southern part (around $100 \mathrm{~mm}$ mean annual precipitation) to hyper-arid in its northern and central parts (around $10 \mathrm{~mm}$ ). Despite extremely high spatio-temporal variability in rainfall there is an overall seasonal pattern, with winter rains in the north and both winter and monsoonal summer rain in the south (Ayyad and Ghabbour 1985). In the south, the rainfall coefficient of variation is around 70 percent while in the north it is about 200 percent (Vose et al. 1992; Andersen 1999). With such great interannual variability, long dry spells are normal climatic conditions in the region. Tribespeople refer to these periods in Arabic as mahl and in Bidhaawyeet as dimim. In English these terms translate most commonly as "drought" (Roper 1928; Wehr 1976; Hudson 2012). This single word does not convey the varied and nuanced indigenous meanings however, and for this reason we minimize its use in discussion and employ it in several translations of informants' expressions as equivalents of mahl and dimim. It must also be noted that due to the capricious spatial distribution of desert rains, statistical records from the region's few meteorological stations in many cases do not align with indigenous oral records of wet and dry periods.

The region's biogeographical and phytogeographical components are a mixture of Saharian, Sahelian, Sudanian, Sahara-Sindian and Mediterranean. Drought-evading herbs and grasses are valuable fodder resources for livestock, but are limited to when and where rain falls. Long-lived drought-enduring trees however are green most of the year and represent the vital perennial source of fodder (Krzywinski and Pierce 2001; Andersen 2012; Andersen et al. 2014).

Acacia tortilis is regionally one of the most abundant woody species in arid North Africa. Its distribution extends eastward to the Arabian peninsula and southward to southern Africa (Brenan 1983; El Amin 1990) and it occurs in a variety of habitats. It is distributed widely throughout the study region and is usually restricted to wadis and sites that receive run-off (Fig. 2). Two A. tortilis subspecies are most important: A. tortilis subsp. tortilis (hereafter referred to as subsp. tortilis) that is more common in the southern part of the study area and dominates smaller wadis and runnels, and Acacia tortilis subsp. raddiana Brenan (hereafter subsp. raddiana) that with some exceptions is found in main wadis indifferent to soil type and often confined to the main watercourses throughout the area (El Amin 1990; El-Awad 1994; Zahran and Willis 2009). In the southern part of the study region Acacia tortilis trees are also found outside the wadis. Acacias are the only arboreal species distributed widely throughout the region.

Andersen (2012) considers today's scattered groves of trees as remnants of a former savannah forest contracted to the most favorable locations. In the mountains such locations are relatively abundant and are found mainly in dry river valleys (wadi, khor). Wadis often form large catchments where moisture from upstream showers and dewfall seeps into subsurface alluvial aquifers (Babiker and Gudmundsson 2004). While rainfall is critical in germination and establishment, established acacias extract water from deep, permanently moist strata and their use of water is stable despite interannual and seasonal variation in soil water availability in the upper soil layers (Do et al. 2008).

In the study area the two subspecies of $A$. tortilis constitute by far the most important reliable vegetation resource for local nomads (Krzywinski and Pierce 2001; Andersen 2012). They provide products such as fodder, fuel, and wood and ecosystem services such as shade and shelter for people and animals, improved soil fertility, and increased biodiversity by providing diverse microhabitats and resources for other species. A. tortilis is thereby recognizable as a keystone species in ecological terms (Munzbergova and Ward 2002). In absolute terms the species diversity and numbers of trees increase southwards 


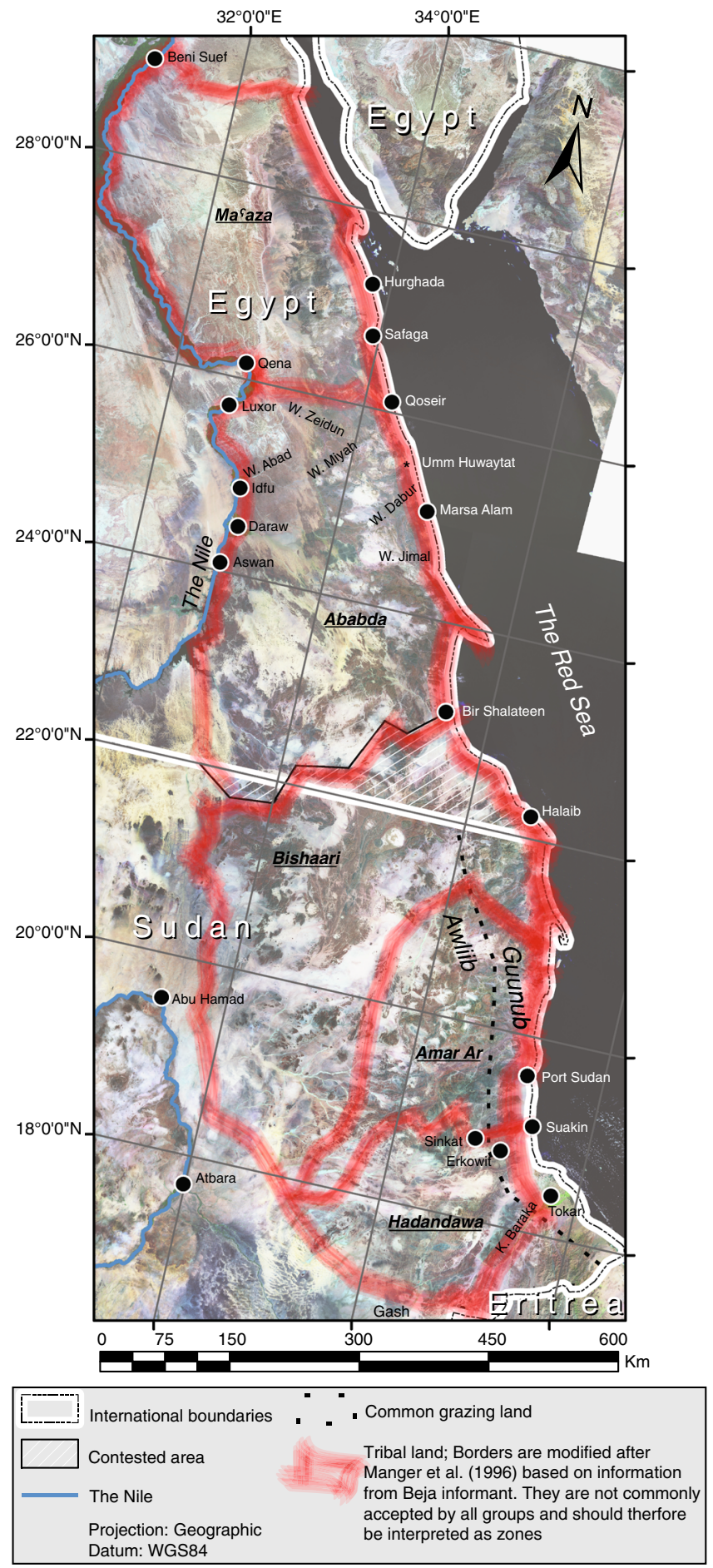

Fig. 1 The Red Sea Hills study area and the tribal territories 


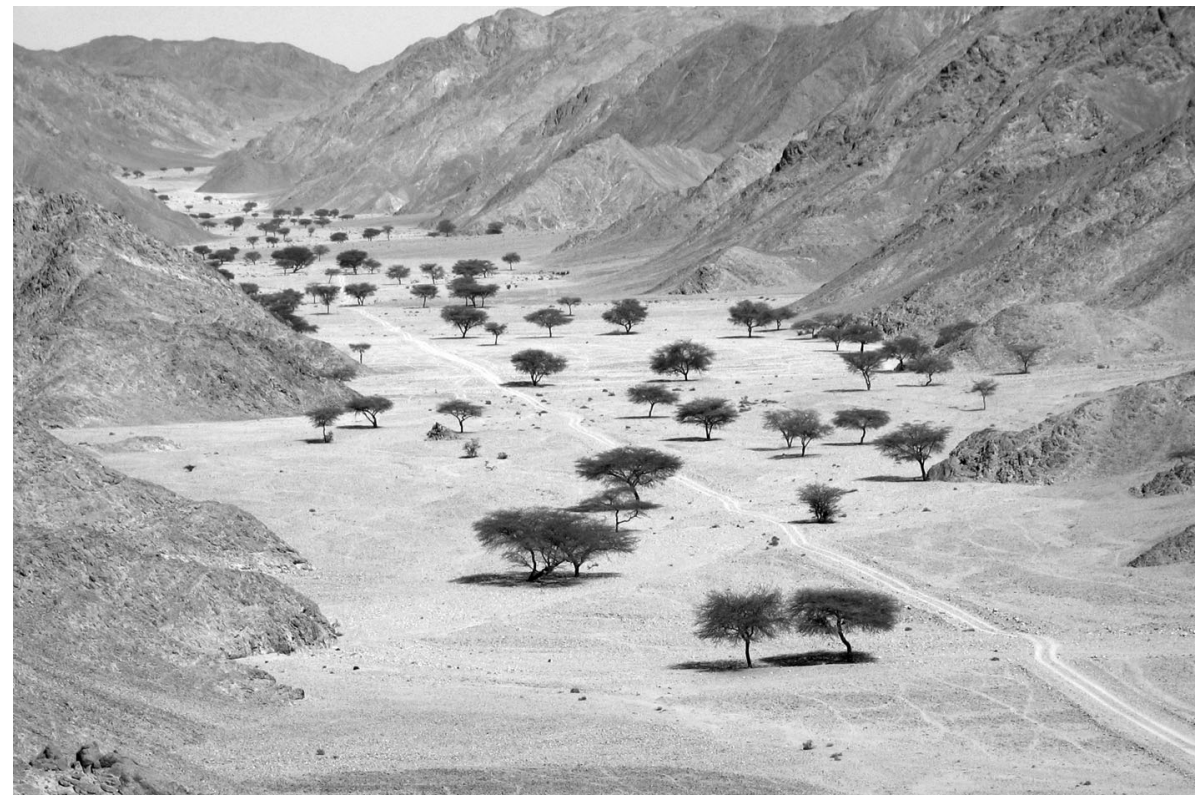

Fig. 2 Wadi Durunkat (in the Wadi Jimal drainage) in the Ababda area, Egypt, has a rich growth of subsp. raddiana. In oral descriptions richness or density of trees is often visualised by one's inability to spot a camel among the trees

along with the moisture gradient. The numbers and cultural diversity of people also increase from north to south.

Within the study area are five major nomadic tribes, from north to south: the Semitic, Arabic-speaking Ma'aza and Ababda, and the Cushitic Bidhaawyeet-speaking Beja: Bishaari, Amar Ar and Hadandawa (see Fig. 1). The latter three are often collectively referred to as the Beja in this paper.

The Ma'aza are Bedouin whose hearth is in northwest Saudi Arabia and who settled in the northern Eastern Desert beginning about 300 years ago (Hobbs 1989). The Ababda, though now mainly Arabic speakers, share a common heritage with the Bidhaawyeet speaking Beja tribes (Riad 1974). The Beja claim to be autochthonous and to have millennia-old antecedents among the Medjay and the Blemmyes, attested to in the archaeological record as early as 1800 BCE (El-Sayed 2004; Liszka 2011; Krzywinski 2012; Näser 2012; Pierce 2012).

All these tribes share a number of culture traits, notably a segmentary patrilineal kinship structure (but see Manger et al. 1996, p. 150 and Hasan 1973, p. 59) in which personal identity, social affiliations and many economic activities are rooted in lineage, clan and tribe (Hobbs 1989; Krzywinski and Pierce 2001; Barnard and Duistermaat 2012; Krzywinski 2012). They also share a strikingly similar use of resources. All tribes have moved about with their animals to optimize uses of fodder (including acacia products) and water resources. The degree and range of their movements have depended on the number and types of their herd animals (Hjort af Ornäs and Dahl 1991) — camels, sheep and goats_-and on the aridity gradient that imposes increasingly rigorous demands the further north they live. 


\section{Acacias in the strategies of pastoral nomadism}

Due to the unpredictable spatial and temporal nature of desert rainfall, these nomads must adapt themselves to uncertainty. They practice an "opportunistic" livelihood, diversifying their economic activities to anticipate or confront distress such as animal disease and pasture failure. Many work for wages or otherwise supplement their pastoral incomes. Their multipronged efforts reveal livelihoods not limited to pastoralism; they practice what anthropologists of nomadism describe as "multi-resource nomadism" based on "risk minimization" (Dyson-Hudson 1972; Salzman 1972; Moritz et al. 2011).

Movement between pastures following rainfall is a common pattern of pastoral nomadism within much of the study area, as is dependence on browse from perennial tree resources. The northern Ababda and the Ma'aza move wherever occasional rain has fallen. The Beja and some of the Ababda in the southern part of their territory practice a seasonal movement pattern, moving within the Awliib (a seasonal pasture area west of Sudan's Red Sea Mountain watershed) after occasional summer and autumn rains and the Guunub (a seasonal pasture area on the coastal plain east of the mountains) after winter rains (see Fig. 1). However, the crucial fodder resource is the acacia trees in wadis and alluvial plains of their specific tribal areas. The Hadandowa also take their animals to graze in the inland deltas of Gash and Tokar/Khor Baraka located in the southern part of the RSH, close to the Eritrean border (Fig. 1). Today these areas are mainly state-owned agricultural schemes, but pastoralists can work there during the cultivation season and can bring their animals to eat the leftovers after harvest (Dec.-Feb.). One means of securing fodder during prolonged dry spells is to move the herd into the territories of other tribal groups where rain has fallen, as permitted by the "usufruct" principle of mutual non-destructive use of resources.

Acacia trees have had enormous importance in the pastoral strategies of the five groups while seasonal ephemeral pasture constitutes an appreciated surplus when available. $A$. tortilis provides its nutritious leaf fodder throughout almost the entire year (Andersen et al. 2014). During the dry season, when the trees have few or no leaves, ripe seed pods of subsp. tortilis are especially valuable. Acacias provide fodder during rainless periods lasting as long as 5-20 years, according to our informants. Preserving the capital of trees, maintaining or increasing their biomass production, and harvesting them are therefore vital.

All these people have harvested tree fodder cut from the branches of subsp. raddiana using similar techniques (they never cut from the multi-stemmed, flat-topped subsp. tortilis because it does not regenerate well after pruning). The pruning techniques are described in more detail in Andersen et al. (2014). People cut off branches from mature trees either to feed their animals or to renew the health of drying, weak or overgrown trees using procedures called waak by Beja, janii by Ababda and tahsiin or taghsiin by the Ma'aza. Collectively these pruning techniques, done mainly by men, are similar to the practice of "pollarding" in Europe and other more humid regions (Rackham 1976; Gilman 2011). To the outsider unfamiliar with them, these techniques may appear to be destructive and lead to judgments about "deforestation." It must be kept in mind however that even the extensive pruning seen in Fig. 3 will lead to a re-florescence of this tree within 2 or 3 years (Andersen et al. 2014).

People use special techniques to strengthen and shape the young tree for subsequent harvesting. From the young subsp. raddiana, the Beja remove branches below canopy height with a technique they call shiishaknooyt ("helping to mature"). Until about 1980 the Ma 'aza used the similar technique of tasliih, meaning "betterment". These practices give 

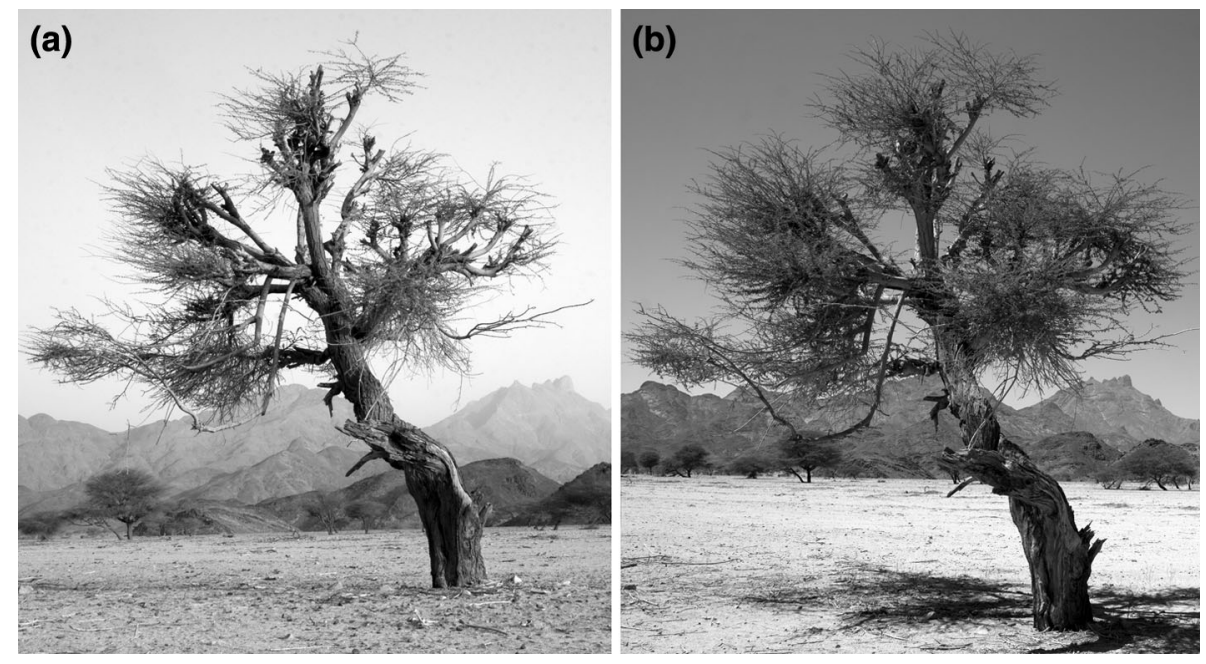

Fig. 3 a A recently pruned subsp. raddiana in the Bishaari area in northern Sudan (Sep. 2010). b The same tree seen in April 2011, already with many new branches. Within a short time (2-3 years) an extensively pruned tree can develop a dense growth of flowering and fruiting branches

the tree its typical shape, with one or two trunks and a defined canopy that offers good, accessible shade. Without these practices trees become difficult to approach and use.

Most informants say pruning is good for a tree, because it cleans and renews it and keeps it "lighter" and "younger." In this context, the pastoralists recognize a relationship of symbiosis or mutualism between themselves and the trees. An Ababda man shared a typical view: "People benefit from the tree and the tree benefits from them."

The most gentle technique for harvesting acacia seedpods ( 'illif Ar., haayt B.), leaves (awraag Ar., bayi B.), and flowers (balla Ar., buukt B.) without cutting branches is shaking (mahrak, miruug B.) with the shepherd's crook (mahjan Ar., antiir B.). It is typically done, often by women or children, for small stock, especially for young weaning or weak animals and for sheep because they do not climb trees as goats do. It can be done throughout the year as long as trees are productive.

Shaking and pruning trees to harvest fodder are ancient tending practices, depicted as early as the Egyptian New Kingdom (1539-1075 BCE; Andersen, 2012). It seems reasonable to assume that pastoralists in the drylands bordering the Nile Valley practiced such techniques in ancient times. That the same tending practices are in use today suggests that rather than overusing their essential tree resources, local peoples long ago developed effective and sustainable techniques for conserving them.

One conceivable way to proliferate the vital acacia tree is entirely absent among all the culture groups, viz. planting it, even though they possess detailed knowledge about seed dispersal, sprouting and regeneration (including the fact that successful regeneration is virtually impossible as several successive rains are needed). Some say simply, "God grows the tree."

The acacias' importance is summarized by a middle-aged Ababda man: "We cannot live without sayaal [subsp. raddiana]. It still survives whether it rains or not, and the animals depend on it on during the mahl. It provides seed pods for animals to feed on for 3 months, and flowers for 2 months. So sayaal provides fodder during mahl." 


\section{Safeguarding the cultural keystone}

Trees and particularly acacias are such important resources to these desert peoples that they share a taboo against cutting down living ("green") trees. "Killing a saganeeb (subsp. tortilis) tree is like killing a man," said a Beja man of the Atman-Alyaab. There is a wide variety of justifications for safeguarding trees as a resource. Some are based on tribal law correlating kinship and territorial units with resource usage, while others are imbedded in social mores and belief systems. The justifications are also based on or intersect with deep histories of accumulated TEK.

Resource use rights correspond with political-geographical territories belonging to kinship groups of tribe (gabiila), clan (far'a or 'ayla Ar., gabiila B.), lineage ('ayla or 'ayaal Ar., dhiwaab B.), household (bayt Ar., g'a B.) and individual. These rights (haqq Ar., damir Ababda, $m$ 'araw B.) are regulated by unwritten tribal law, known as silif (B.) and 'urf(Ar.) (Hjort af Ornäs and Dahl 1991; Manger et al. 1996). At the largest territorial level, resources including trees, seasonal pastures and water resources nominally belong equally to all members of a tribe. Within a territory actual responsibilities for resources are increasingly associated with lower levels of the tribal hierarchy. Resources within a clan territory are common property of the clan and may be used as usufruct by non-clan members (whether from the same or different tribes) with the clan's permission. Guests in Beja lands must acknowledge the rights of their host (often by giving gwadab B.: "token payment for use of land by the usufruct right holders to the owners"; Manger et al. 1996). In general guests' animals can graze ephemeral vegetation and browse trees and take shaken products, but guests cannot "harm trees or dig wells ('turn stones')." Other uses of perennial resources including acacias (cf. above) are more restricted and vary among the culture groups.

Among the Beja, acacias that belong collectively to clan members are subdivided into effective responsibilities of households, according to their $m$ 'araw right. The Hadandawa guideline is that a man has the right to use and is responsible for "the trees in the view from his home." The rights and obligations are lost if a group leaves the land. When a tribal (sub)group moves, land and its resources can be taken by others. Therefore, for example, when Beja groups move seasonally, some families or family-members often stay behind to protect their rights in that specific area.

Tribal law metes out punishment for violations, including cutting down green trees or pollarding trees without permission. Disputed issues are decided in gatherings (majlis Ar., meglis B.) on the initiative of the disputing parties on the basis of consensus. There is also an official forestry department in Port Sudan that regulates the use of forest resources in the Beja territory. Cutting down live trees is banned by the forestry department, but our informants comment on its lack of efficiency in protecting acacias in the Sudanese RSH. The effectiveness of tribal law in safeguarding many important aspects of traditional desert livelihoods has, however, been well documented (e.g. Kennett 1925; Al-Krenawi and Graham 1999; Stewart 2006). Our sources concur that from early times, tribal control has successfully protected trees from destruction, and in most of the area still does. Without these laws there would be more opportunities for abuse, including the overcutting of living trees that would threaten the viability of the tree populations and thereby the pastoral livelihood.

People protect acacias for many more reasons than fear of tribal law. Our fieldwork has revealed numerous ways in which acacias are culturally valued. Some trees even become important "personalities" on the cultural landscape, earning extra protection. A. tortilis can live for several centuries (Andersen and Krzywinski 2007a 961; Goslar et al. 2013), and as 
long as people perpetuate oral traditions they pass along tree biographies. In some cases a man explicitly identifies a tree with himself: for example four generations ago a man named Ruwa'iy of the Ma'aza Ashhab clan pointed to his favorite acacia and said, "If anyone cuts it I will cut him!" This "autographed tree" was henceforth known as Sayaalit Ruwa iy and had special status until its death in the 1990s. The place it occupied is still identified as a landmark in Ma'aza conversation and wayfinding (Hobbs 2014). Personalization of trees is characteristic of Ababda and Beja cultural landscapes as well. An Ababda man of the Saliim clan recited some of his peoples' acacia "nicknames," including Abu Jamal or "Father of the Camel" for the acacia under which a camel died and $A b u$ Kakar or "Father of the Viper" in the shade of which snakes were encountered. The Hadandowa have a tree called Ohaj Tawaay after a revered spiritual leader named Ohaj, and their "Omda's Tree" is named for one of their tribal leaders.

Some of the most important cultural components of the nomads' lives are kinship, faith, and dualities of permissible/forbidden and honorable/shameful. Aspects of these are prominent in establishing the acacia among the Hadandawa, Amar Ar, Bishaari, Ababda and Ma'aza as a "cultural keystone species," defined by Garibaldi and Turner (2004) as "culturally salient species that shape in a major way the cultural identity of a people, as reflected in the fundamental roles these species have in diet, materials, medicine, and/or spiritual practices."

Acacias feature prominently in important stages and places of the pastoralist's life. In most Islamic cultures there is segregation of space by gender, with public space being male and private space female. The acacia tree's precinct is public and male space, a fact that is often reestablished ritually with the Beja boy's birth in the desert: his afterbirth is hung on an acacia branch, or buried under the tree (Fadlalla 2007) (Fig. 4). Informants explain that this portends the man's ventures outdoors in the wider world. In contrast, a newborn girl's placenta is buried under the tent or hut (which is the property of the mother) to foreshadow her rootedness in the hearth of her desert homeland.

There are other associations with phases of acacia and human life. From the pre-Islamic practice of purification after having sex, a Beja man may jump over a small acacia in its early, dehanoot, lifecycle stage (as a sapling, associated with virginity since such a tree has not yet come of age with its first flowering). It is also notable that the management technique shiishaknooyt is named by the same word used to describe circumcision and the first cutting of a boy's hair, both of which mark socially recognized stages of human life. The underlying intent is to help trees and people to attain maturity and realize their potential.

While men socialize in the tree's shade, for the sake of both people and trees it is "not good" for women to linger around or even approach acacias. The trees are well known for making young women ill. A Hadandawa woman (age 60) said, "trees make young women sick," adding that they "are not always clean" and so should not come near the trees. It is also said that women of child-bearing age should not come near trees. A Hadandawa woman in Erkowit said "young women should not use trees; devils will get on them if they do". Shaking trees for leaves and pods is mainly the responsibility of women and children, who should only shake trees deemed "safe," and only in daytime. Women sometimes pollard such trees. Some of the perceived risk is actually to the tree: unclean women can make trees less productive, a state compared to an allergic reaction (fighat; B.) by some informants.

Acacias have spiritual and religious connotations that invigorate the "secular" ban on killing trees. A Hadandawa man asserted that "Islam forbids the cutting of green trees". Although most of them are not literate, the pastoralists are familiar with passages from the 


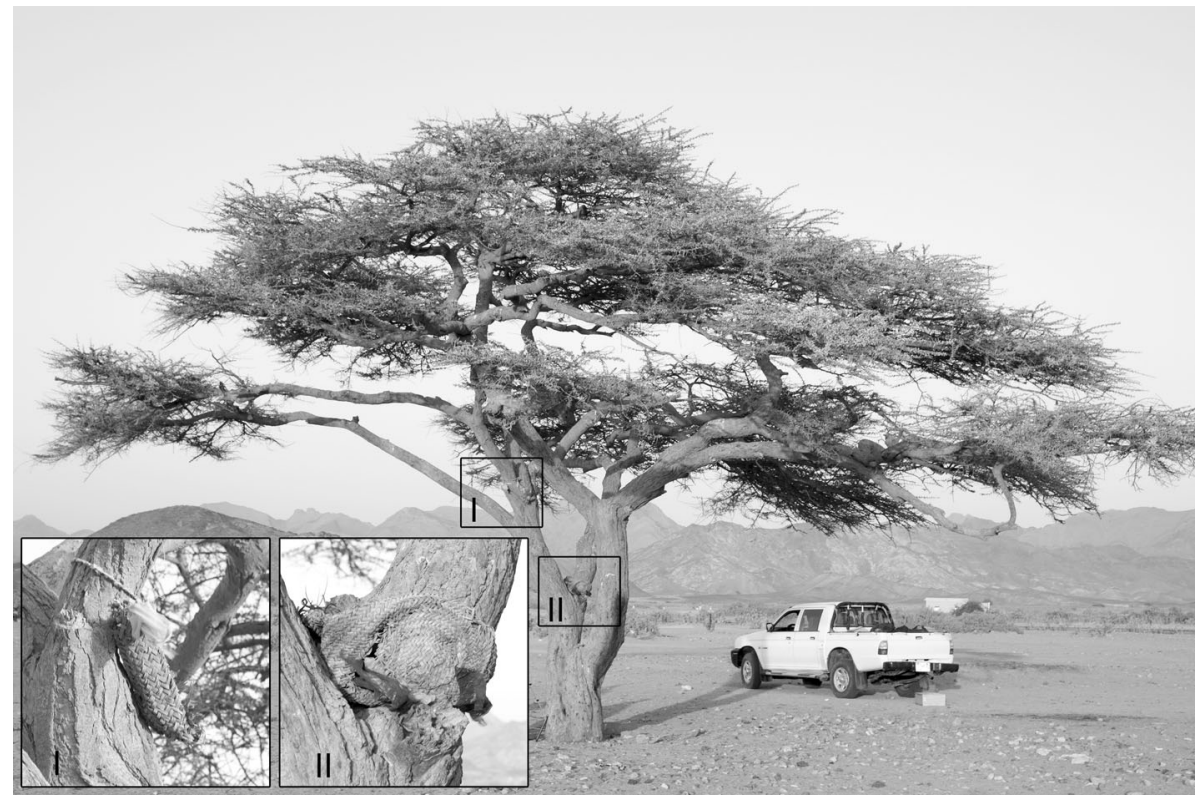

Fig. 4 A "boy's tree" in Gebeit, close to Sinkat. The two baskets (I and II) contain the afterbirth of baby boys. Today this is also practiced symbolically by hanging up empty baskets

Qur'an and Hadith, including the Hadith verse "Anyone who cuts a Zizyphus tree which is in the desert and that can be used for shade by travelers or animals without any right: God will cast him into Hell" (Almaqdisi 2014, p. 443). The desert people do not mention the Zizyphus tree specifically, but have transferred the prohibition to all living trees. One of our Ababda informants commented, "Green trees should not be cut. It is said that the people who harm trees get punishment at the end." A Hadandawa man said, "cutting down trees brings evil." In some cases even pollarding some trees could have consequences: Ababda elders would warn, "do not cut from this tree, otherwise the spirits will attack you or your arm."

Many spiritual admonitions about trees have roots in folk beliefs, some perhaps dating to pre-Islamic times. All the culture groups believe that trees near water and graves in particular should not be cut down. Prohibitions regarding graves, including not walking on them, apply to the pre-Islamic Beja tombs (akrateheels B.) found throughout all the tribal territories and honored by Beja as graves of their ancestors. According to Hadandawa sources the people buried in akrateheels, said to have been large and strong, are "not completely dead." There are numerous accounts of the spiritual beings, called hamaashragadiit (B.), inhabiting akrateheels. Not all are evil, and in fact some advise and otherwise help the living. These often-bearded entities have the power to "steal your mind," and children in particular should keep their distance lest they go mad, according to Hadandawa women. Some akrateheels contain burial goods, often gold, and their protector spirits will make grave-robbers insane. Clearly, people are more likely to avoid harming trees associated with akrateheels.

The consequences may be even worse: an 11 year old Amar Ar boy claimed that if you cut down a living tree it would weep, and wild beasts would come to kill you. There would 
also be an emotional toll on a perpetrator, he said: cutting down a green tree would make one mad. A group of Hadandawa boys said that acacia trees should not be used in any way in the evening, and numerous informants made it clear why: night is the preferred time of the jinn (Ar.)/whiinaayt (B.) or "genies" and other malevolent spirits of the underworld that are a particular hazard to girls and pregnant women. Many have faces on both the front and back of the head. They travel with their animals at night, when one may hear them as they pass by. Both male and female jinn may be attracted to humans, and some manifest themselves as beautiful girls to seduce men.

Like people, jinn are fond of trees and prefer thornless varieties. Acacias with long spines (they are often more than five $\mathrm{cm}$ ) are a nuisance to jinn, and people therefore consider them safe. Jinn prefer to haunt acacias that are isolated, large, and have dense and unkempt growth, or that have almost night-like shade (therefore being unsuited for peoples' daytime naps). Acacias that host the climber Cocculus pendulus invite jinn and are a particular threat to women. Jinn harbor their young in trees' shade, where if people should harm them (even by unintentionally stepping on and crushing them) the parents will render them deaf, blind or lame. A Beja said that jinn breed and deliberately release flying pests (d'oob B.) that feed on acacias.

There are ways to protect oneself in the precinct of an acacia. An Ababda man explained that the simple utterance Bismillah al-Rahman al-Rahiim, "In the Name of God, the Compassionate, the Merciful," should be spoken by anyone about to manipulate an acacia in any way. A Ma'aza man said ominously, "If you do not say Bismillah when dealing with the tree you might not be able to move your hands and legs afterwards." For all the culture groups, invoking God before handling an acacia not only deters evil but acknowledges the tree as God's gift to people. An Ababda man said that one should say Bismillah even to stay in the tree's shade, and before pollarding one must explain one's intention in coming to the tree and seeking its permission, saying "we ask for peace; we ask for living." This petition means"we are here to benefit from you without harming you, and ask that you not harm us."

Special rituals are reserved for sacred trees and trees having medicinal properties (Dafni 2006) (Fig. 5). Traditional healers (fagiiri, hakim B.; haawi Ar.) instruct users and petitioners to be clean, and inform them from what directions and times of day they should approach the tree. The supplicant seeking to fulfill a wish can do a karama (an offering) or good deed for the tree, especially by sacrificing a goat. The supplicant invites male members of the group to participate. After the ritual meal he expresses his wish and the group's spiritual leader "reads the book" by extending his hands flat and upright and praying, "Let allah help the tree to fulfill your desire."

The multifaceted values that these pastoral nomadic peoples associate with acacias reveal the tree as a cultural keystone species. The pastoralists have many incentives to safeguard this keystone for sustainable uses, and have long been successful in doing so, perpetuating the distinctive cultural landscapes of eastern Saharan pastoralists. The nomads themselves however express concerns about the future of their landscapes and livelihoods, which are in a period of unprecedented change.

\section{Uprooting people and trees}

The traditional balance between people, trees and other resources in the region is being affected by a number of stresses and stimuli. These include increased vulnerability to dry spells, changing market conditions, new economic opportunities, sedentarization, and 


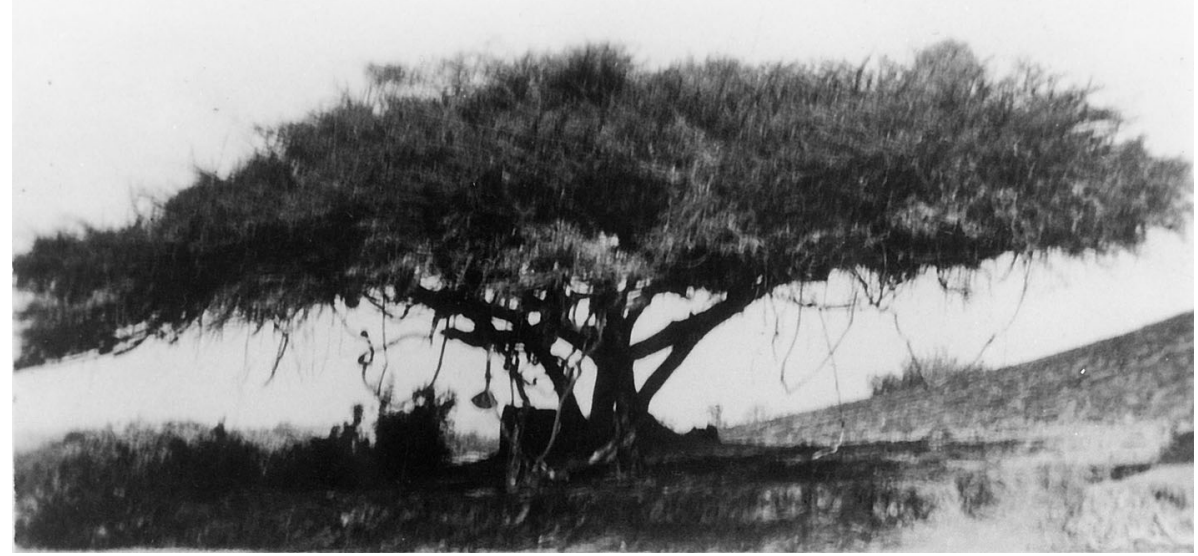

Fig. 5 This acacia tree in Sinkat, regarded as sacred for the Hadandawa people, was already documented by GH Barter between 1928 and 1932 (SAD.474/21/78; Reproduced by permission of Durham University Library)

famine relief (Krzywinski and Pierce 2001; Hobbs and Tsunemi 2007; Barnard and Duistermaat 2012). These forces have affected pastoralists and introduced changes on the cultural landscapes in distinctive ways.

In the northernmost region, it is remarkable that there are any acacias at all: they were on a pathway to elimination, and exist today only because people reversed course. Taking advantage of high market prices for charcoal in those portions of the study area adjacent to the most densely populated areas of the Nile Valley, the Ma'aza extensively charcoaled live trees for charcoal between the late 19th century and about 1950 (Hobbs 1989). Although charcoaling a living tree is forbidden in all tribal groups, to do so is a powerful temptation to resist because charcoal means money for poor people. Ma'aza people continued charcoaling until what they described as a decade-long drought afflicted them during the 1950s. As ephemeral pasture failed altogether in their homeland and adjacent Ababda lands to the south, they recognized that their acacia reserves were critically low. Numerous families left the desert and settled around the eastern margin of the Nile Valley opposite Beni Suef during the drought, but those who remained adopted a complete ban against cutting larger branches and fed their animals mainly with shaken leaves and pods.

The Ma'aza took a number of steps to keep their existing acacia resources and stave off destruction of living trees. One was to emphasize territorial and kinship rights and responsibilities to acacias based more on lineage (a sub-clan), household and individual than on tribe and clan. Acacias that belonged collectively to clan members remained so nominally but were subdivided into effective properties of their families, according to rights within traditional law ('urf Ar.). They proclaimed protected groves of trees on a family-by-family, wadi-by-wadi basis (Hobbs 1989). The claimant's direct male descendants, and thus eventually his entire lineage, became responsible for protection in the future. These 'lineage preserves' were intended to serve as a kind of drought insurance that would protect the desert way of life in any future emergency. Ma'aza people today insist that acacia trees rescued them and enabled their way of life to survive the 1950s. 
Due to push and pull factors driving and drawing Ma'aza people out of the desert, that way of life has all but ended. As recently as the 1980s many hundreds of Ma'aza tribespeople, mostly of the Khushmaan clan, practiced nomadic pastoralism. Only a handful of families do so today. With another prolonged dry spell and a boom in Red Sea tourism in the 1990s, most of the desert-dwellers were drawn into a state of "soft sedentarization" at 14 encampments (mahatta) on the coastal plain near Hurghada (Hobbs and Tsunemi 2007). Egyptian guides bring international tourists on half day "safaris" from beach hotels to see "how the real Bedouin live". In 2013, on the eve of the coup and subsequent violence that wracked Egypt's tourism industry, about $200 \mathrm{Ma}$ 'aza families were encamped at these sites. A few kept sheep and goats in penned areas there, but most of their income came from tourism at the stations and from wage labor in Hurghada.

Acacias on the cultural landscape of the Ma'aza at present have several distinctive features. While their numbers are small compared with populations further south, there are several dispersed groves of trees. Each of these is associated with the memories of particular men who spoke up for them in the mid-Twentieth Century. Individual trees and smaller groves in places that people and herds commonly visited and stayed in the recent past still have characteristic well-groomed shapes. Neglected by people and livestock, acacia trees in more remote locales have developed signs of less use, such as having a dense canopy, many branches growing around the base, and many dry branches. These are the unkempt qualities that traditional pollarding techniques prevented in order to renew and make maximum use of acacia resources. In addition, on the Ma'aza cultural landscape a selection of sites visited in December 2011 have a notable increase in mature trees compared to high resolution imagery from the 1960s (unpublished results, but see Andersen (2006) for methodology).

Interviews and experiences with Ma'aza informants reveal that although the trees are no longer actively used for sustenance, Ma'aza people still prize and protect them. The modern Ma'aza homeland with its remaining acacia populations is a remnant cultural landscape originally shaped and maintained by Bedouin culture and now transforming into an abandoned, yet culturally-guarded, landscape. After being threatened by extinction the trees presently enjoy protection and are valued by the Ma'aza. On this cultural landscape it is critical to appreciate what people are not doing.

Although the Ababda and Beja tribes include numerous widely spread subgroups, broadly similar trends are affecting their cultural landscapes and acacia trees. Ababda and Beja informants concur that the numbers of their desert-dwelling kin are declining. However, particularly in the south and in the most remote areas studied there are still active pastoralists. Some keep large flocks and are highly mobile; others have so few animals that seasonal movement is unnecessary. In general, although pastoralists' trees are still well tended for feeding livestock (Andersen et al. 2014), ongoing abandonment and sedentarization are altering their vegetation resources. An Ababda man enumerated the wadis that had been abandoned and remarked on the consequences for acacias, "In each big wadi, people used to dig wells and herd animals around them. They protected the place and the trees living in it. But now there are no people like before." Both Ababda and Beja informants observe that acacia numbers are declining in their tribal territories, and they express their concern about this in nostalgic reminiscences of a more verdant world. A Hadandawa man said: I have heard from old people that the Hamoot area [hilly area on the west bank of Arba'aat] used to be full of trees. It still has some but everything is changed diversity, climate." A man of the Atman-Alyab had an even wider view: "All eastern Sudan was forested, but now all the khors are empty and the number of trees is decreasing." An Ababda source from the Saliim clan said that previously acacia numbers were 
greater than they are now, adding, "In Wadi Zeidun it is said that people could not see their animals due to the density of acacia trees" (see Fig. 2).

A number of cultural and environmental explanations for declining acacia populations must be considered. Change analyses using 1960s satellite imagery compared with the recent situation confirm that acacia populations in the Ababda territories have had high mortality and low recruitment (Andersen and Krzywinski 2007b). Only some of this observed mortality pattern could be attributed to water conditions, as revealed by digital elevation modelling (Andersen and Krzywinski 2007b). Asked to explain declining tree populations, many informants, however, cited drought (mahal Ar., dimim B.): it was held responsible for decimating the Wadi Zeidun forests, according to the Ababda man who described them. An Ababda man of the Ballalab clan remarked, "15 years ago when I came to Wadi al Miyah, there were more acacias than in these days. Wind fells many trees. Many trees also die due to drought. "An Ababda man of the Haranab clan said in October 2010 that a drought longer than 10 years had taken many trees' lives, and noted a change in rainfall patterns:

"Before, rain normally fell twice a year, and it used to rain over many days. Now rains fall little from time to time. It has been about 12 years of drought now. The trees are in great stress. The water table in wells is low. For example, the well of Umm Huwaytat is dry now and many trees died already. Even in this Wadi (W. al Miyah), many Sayaal trees died, also in Wadi Dabur and Wadi al Jimal."

An Ababda man of the Farhanab said:

"Sayaal is very strong and resists drought if it is not too long. A few individuals may die due to drought, but not many. Sayaal trees do not die from diseases. But some die without reasons: like humans, everything has its time to die."

Some people blame deforestation on human agents rather than drought. "Drought does not cause all trees to die," a Hadandawa man said, "man is their major killer." When interviewed, people almost invariably say they protect trees and that others are to blame for killing them. Several Ababda sources blamed road construction and mining crews for chopping down trees. Locals believe that where they leave the desert, losing the ability to monitor resource uses, more opportunities for abuse by non-indigenous outsiders open up. An Ababda man in Wadi al Miyah said:

“Acacias without people around them will not survive very well, for example in Wadi Abad. Fifteen years ago in this wadi you could hardly recognize animals' movements due to the huge numbers of acacias. But then people from outside came and removed many of these trees and started cultivating in the wadi. This was because there was no guarding in the area."

Despite the universal prohibition of cutting down green trees, some desert people are doing so. A Hadandawa man said, "People even cut green trees if they cannot be seen by those who would stop them from cutting. Cutting is common, but we are trying to keep them from being cut." Growing urban demands for acacia firewood and charcoal provide incentives that overpower the traditional Beja stigma on charcoalers as poor people (Christensen 1998). Surges in charcoal demand often correspond with developments of transportation and urban growth corridors, such as along the Suakin-Atbara railway (completed 1905) and the road that parallels it (opened in 1980) (Christensen 1998).

Fewer people on the landscapes intuitively suggest less pressure on Ababda and Beja trees. Impacts on trees, however, vary according to how individual wadi/tree owners interpret their rights/responsibilities. Most owners do protect and sustainably use their 
trees. In explaining how people benefitted acacias, an Ababda man said, "the first thing is protection, people who live in wadis protect their trees." Others however profit by charcoaling or arranging for others to charcoal their trees. This is especially true in areas most strongly influenced by social and economic transformations and in areas close to settlements. Many Beja claiming personal ownership of trees near their homes interpret tribal law to mean they have the right to cut down living trees for charcoal (cf. also Christensen 1998). Commercial charcoal production is increasing to the degree that in some places charcoaling has become the main source of Beja income. Hadandawa informants say that some people who have settled in towns pretend that they are only temporarily away and return periodically to exercise their rights to trees-including making charcoal. Ababda sources report that in some places a wadi owner lets someone else do the charcoaling on his land and takes a commission of one-third of the product. In such cases the individualisation of rights to trees is abused, with negative effects on the ecosystem. There is growing alarm among the Beja about these consequences, and some have taken action. For example, the Turkwei (Hadandawa) south of Erkowit recognized that killing off trees was not sustainable and like the Ma'aza imposed bans on charcoal kilns (kamina) in the late 1990s (Christensen 1998).

A number of informants say that in the process of sedentarization and other social changes traditional laws have broken down, opening the door for abuse of trees and other resources. To varying degrees among the tribes, with the decline of traditional pastoral nomadic resource uses these laws are losing their influence and relevance. An Ababda man remarked, "Before, there was the shaykh. If someone damaged or cut a tree, they called for him to apply the traditional laws. Everyone protected his region, but now all the laws are gone and these people are gone too." We asked a Hadandawa man whether people ask one another to protect their trees and he said, "Yes-but no one listens".

Another consequence of sedentarization having great impact on acacias and other resources is the loss of traditional environmental knowledge. Ironically, according to our sources, formal education is a major cause of this loss. "The new generations get educated, and they live in the towns," an Ababda man of the Haranab clan explained. "The school education is not like the Arab traditional education. Elders who teach and give the first lessons on the desert are gone. "An Ababda of the Blalab clan added that the educated children that live in the town "cannot live in the desert any more."

Most of our informants concur that once their kinsmen have settled down and adopted these new knowledge systems they do not return to desert life. It is remarkable that in recent years, many central Saharan nomads have chosen to remain in the desert explicitly because they have seen those who settle lose their desert knowledge, become poor, and find themselves unable to fall back on to the security provided by traditional knowledge and skills. Jeremy Keenan writes that "'the failure of modernization to deliver on its promises' is leading to a degree of nomadic cultural revivalism across much of the central Sahara" (Keenan 2006 p. 705). For our study area, we have only speculated whether abundant rains, the decline of tourism, political events or other variables might lead to a similar resurgence or restoration of desert-rooted livelihoods. Well informed decision making about desert development could also play a role.

\section{Conclusion}

Our research in a large area of the RSH reveals that tribal pastoral nomadic peoples with different ethnic and cultural roots have developed analogous ecological knowledge about 
how to manage their vital acacia resources with optimal efficiency. Through the generations they have passed that learning down as what we recognize as traditional ecological knowledge. This TEK has helped them to develop sustainable indigenous resource management strategies and tactics protecting the vital services of this ecological keystone species and thereby enabling their life in the desert. These peoples have a rich body of cultural associations with acacias that also generally help to safeguard the trees. The acacia is a cultural keystone whose attributes draw from and contribute to the social, spiritual and moral characteristics of people who value the tree.

Acacia management has long played a central role in moulding and maintaining the cultural landscapes of the RSH. These landscapes represent an enduring and largely successful human relationship with nature. Ongoing detrimental changes affecting acacia populations in the study area correlate more strongly with social impacts than with climatic factors. Social and economic pressures on cultural and natural resources are severing the intimate bonds between nature and nomadic culture. Ongoing social and economic changes and sedentarization among nomads may have strong and lasting environmental costs. Understanding and addressing these linkages are critical challenges for social and natural scientists and policy makers.

Our research challenges views, long held by national decision makers and still strong among some scientists, that nomads are agents of deforestation and ecological destruction and must be rehabilitated. Dawn Chatty points to such views as evidence of the "philosophical and political bankruptcy of state policy which is supported by convenient but untested 'pseudo' scientific assumptions imported from the West" (Chatty 2006, p. 752). Further, our research suggests that modernization and development schemes, food security, environmental conservation and other strategies for dryland development should consider maintenance and reestablishment of local traditional pastoralism as viable alternatives to agricultural development and other unsustainable land uses in deserts and drylands. The concepts of both cultural keystone species and cultural landscapes, so crucial to our understanding of people/tree relationships, are also relevant to ecological conservation and restoration. These concepts provides an opportunity to work with (not on behalf of) local communities to reestablish relationships with places and resources that are crucial to ecological conservation and restoration (Garibaldi and Turner 2004). Protecting traditional cultural landscapes helps to maintain biological diversity. However, to protect the cultural landscape it is necessary to support and empower the peoples and the culture that have maintained it, in this study area for thousands of years. It is more important than ever to document and understand the dynamic forces in motion and the concurrent changes in indigenous perspectives on resource management, particularly because these insights will have valuable roles to play in development going forward.

Acknowledgments Thanks to all informants for their hospitality and willingness to share time and knowledge with us. Interviews of female Beja were possible thanks to Maryam Hasaballa, Hadiya Adarob Ahmed and Amna Iman. Red Sea University arranged visas and travel permits in Sudan. We also thank two anonymous reviewers for their constructive comments. This study is part of the ACACIA project (\#196087), funded by the Norwegian Research Council. Olaf Grolle Olsen and Miranda Bødtker foundation of University of Bergen supported fieldwork.

Open Access This article is distributed under the terms of the Creative Commons Attribution License which permits any use, distribution, and reproduction in any medium, provided the original author(s) and the source are credited. 


\section{References}

Agrawal A (1995) Dismantling the divide between indigenous and scientific knowledge. Dev Change 26 (3):413-439. doi:10.1111/j.1467-7660.1995.tb00560.x

Al-Krenawi A, Graham JR (1999) Conflict resolution through a traditional ritual among the Bedouin Arabs of the Negev. Ethnology 38(2):163-174. doi:10.2307/3773981

Almaqdisi MbM Al-Adab Al Shar'iya wa Alminah Almar'iya (2014) vol 3

Andersen GL (1999) Change and variation in a hyper-arid cultural landscape: a methodological approach using remote sensing timeseries (LANDSAT MSS and TM, 1973-1996) from the wadi vegetation of the Eastern Desert of Egypt. cand. scient. thesis, University of Bergen/NERSC, Bergen

Andersen GL (2006) How to detect desert trees using CORONA images: discovering historical ecological data. J Arid Env 65(3):491-511. doi:10.1016/j.jaridenv.2005.07.010

Andersen GL (2012) Vegetation and management regime continuity in the cultural landscape of the Eastern Desert. In: Barnard H, Duistermaat K (eds) The history of the peoples of the Eastern Desert. Cotsen Institute of Archaeology, Los Angeles, pp 126-139

Andersen GL, Krzywinski K (2007a) Longevity and growth of Acacia tortilis; insights from 14C content and anatomy of wood. BMC Ecol 7(4):4. doi:10.1186/1472-6785-7-4

Andersen GL, Krzywinski K (2007b) Mortality, recruitment and change of desert tree populations in a hyper-arid environment. PLoS ONE 2(2):e208. doi:10.1371/journal.pone.0000208

Andersen GL, Krzywinski K, Talib M, Saadallah AEM, Hobbs JJ, Pierce RH (2014) Traditional nomadic tending of trees in the Red Sea Hills. J Arid Env 106:36-44

Ayyad MA, Ghabbour SI (1985) Hot deserts of Egypt and Sudan. In: Evenari M, Noy-Meir I, Goodall DW (eds) Hot desert and arid shrublands, B, vol 12B., Ecosystems of the worldElsevier, Amsterdam, pp 149-202

Babiker M, Gudmundsson A (2004) The effects of dykes and faults on groundwater flow in an arid land: the Red Sea Hills, Sudan. J Hydrol 297(1-4):256-273. doi:10.1016/j.jhydrol.2004.04.018

Barnard H, Duistermaat K (eds) (2012) The history of the peoples of the Eastern Desert. Cotsen Institute of Archaeology, Los Angeles

Berkes F (2008) Sacred ecology, 2nd edn. Routledge, New York

Birks HH (1988) The cultural landscape past, present, and future. Cambridge University Press, Cambridge

Brenan JPM (1983) Manual on taxonomy of acacia species: present taxonomy of four species of Acacia (A. albida, A. senegal, A. nilotica, A. tortilis). FAO UN, Rome

Briske DD, Fuhlendorf SD, Smeins FE (2003) Vegetation dynamics on rangelands: a critique of the current paradigms. J Appl Ecol 40(4):601-614. doi:10.1046/j.1365-2664.2003.00837.x

Chatty D (2006) Assumptions of degradation and misuse: the Bedouin of the Syrian Badiya. In: Chatty D (ed) Nomadic societies in the Middle East and North Africa: entering the 21st century. Brill, Leiden, pp 737-758

Christensen A (1998) Faham fi! Charcoal production as part of urban-rural interaction in the Red Sea Hills, Sudan. cand. polit. thesis, University of Bergen, Bergen

Dafni A (2006) On the typology and the worship status of sacred trees with a special reference to the Middle East. J Ethnobiol Ethnomed 2(26):26. doi:10.1186/1746-4269-2-26

Davis DK (2005) Indigenous knowledge and the desertification debate: problematising expert knowledge in North Africa. Geoforum 36(4):509-524. doi:10.1016/j.geoforum.2004.08.003

Do FC, Rocheteau A, Diagne AL, Goudiaby V, Granier A, Lhomme JP (2008) Stable annual pattern of water use by Acacia tortilis in Sahelian Africa. Tree Physiol 28(1):95-104

Dyson-Hudson N (1972) The study of nomads. J Asian Afr Stud 1972(7):2-29

El Amin HA (1990) Trees and shrubs of the Sudan. Ithaca Press, Exeter

El-Awad AA (1994) Eco-taxonomical studies in the Red Sea Hills. University of Khartoum, Sudan

Ellis JE, Swift DM (1988) Stability of African pastoral ecosystems-alternate paradigms and implications for development. J Range Manag 41(6):450-459. doi:10.2307/3899515

El-Sayed R (2004) r' n Md.iw-lingua blemmyica-tu-bedawie. Ein Sprachenkontinuum im Areal der nubischen Ostwüste und seine (sprach-) historischen Implikationen. Studien zur Altägyptischen Kultur 32:351-362

Fadlalla AH (2007) Embodying honour. Fertility, foreignness, and regeneration in Eastern Sudan. The Univeristy of Wisconsin Press, Madison

Garibaldi A, Turner N (2004) Cultural keystone species: implications for ecological conservation and restoration. Ecol Soc 9(3):1

Gilbert H (2013) 'Bedouin overgrazing' and conservation politics: challenging ideas of pastoral destruction in South Sinai. Biol Conserv 160:59-69. doi:10.1016/j.biocon.2012.12.022

Gilman EF (2011) An illustrated guide to pruning, 3rd edn. Delmar Cengage Learning, Clifton Park 
Goslar T, Andersen GL, Krzywinski K, Czernik J (2013) Radiocarbon determination of past growth rates of living Acacia tortilis trees from two arid sites in Eastern Sahara. Radiocarbon 55(2-3):1683-1692

Hasan YF (1973) The Arabs and the Sudan: from the seventh to the early sixteenth century, 3rd edn. Khartoum University Press, Khartoum (Reprint First edition published by Edinburgh University press)

Herrmann SM, Hutchinson CF (2005) The changing contexts of the desertification debate. J Arid Env 63 (3):538-555. doi:10.1016/j.jaridenv.2005.03.003

Hjort af Ornäs A, Dahl G (1991) Responsible man: the Atmaan Beja of North-eastern Sudan, vol 27. Stockholm Studies in Social Anthropology, Stockholm

Hobbs JJ (1989) Bedouin life in the Egyptian wilderness. University of Texas Press, Austin

Hobbs JJ (2014) Bedouin place names in the Eastern Desert of Egypt. Nomadic Peoples 18(2):33

Hobbs JJ, Tsunemi F (2007) Soft sedentarization: bedouin tourist stations as a response to drought in Egypt's Eastern Desert. Hum Ecol 35(2):209-222. doi:10.1007/s10745-006-9052-y

Homewood K, Randall S (2008) Ecology of African pastoralist societies. James Currey, Ohio University Press, Oxford

Hudson RA (2012) A dictionary of Beja. http://www.rogerblench.info/Language/Afroasiatic/Cushitic/Beja $\% 20$ Dictionary.pdf

Huntington HP (2000) Using traditional ecological knowledge in science: methods and applications. Ecol Appl 10(5):1270-1274. doi:10.2307/2641282

IISH Guiding Principles. Institute for Integrative Science and Health. http://www.integrativescience.ca/ Principles/. Accessed Jan 2014

Keenan JH (2006) Sustainable nomadism: the case of the Algerian Tuareg. In: Chatty D (ed) Nomadic societies in the Middle East and North Africa: entering the 21st century. Brill, Leiden, pp 682-709

Kennett A (1925) Bedouin justice: laws and customs among the Egyptian Bedouin. Kegan Paul, London

Krzywinski K (2012) The Eastern Desert tombs and cultural continuity. In: Barnard H, Duistermaat K (eds) The history of the peoples of the Eastern Desert. Cotsen Institute of Arcaeology, Los Angeles, pp 140155

Krzywinski K, Pierce RH (eds) (2001) Deserting the desert a threatened cultural landscape between the Nile and the sea, 1st edn. Alvheim og Eide Akademisk Forlag, Bergen

Krzywinski K, O’Connell M, Küster H (eds) (2009) Cultural landscapes of Europe, fields of Demeterhaunts of Pan. Aschenbeck \& Oeljeschläger, Delmenhorst

Lamprey HF (1983) Pastoralism yesterday and today: the overgrazing problem. In: Bourlière F (ed) Ecosystems of the world Tropical Savannas, vol 13. Elsevier, Amsterdam, pp 643-666

Liszka K (2011) "We have come from the well of Ibhet" Ethnogenesis of the Medjay. J Egypt Hist 4:149171

Manger LO, Abd el Ati H, Sharif H, Krzywinski K, Vetaas OR (1996) Survival on meagre resources: Hadendowa pastoralism in the Red Sea Hills. Nordiska Afrikainstitutet, Uppsala

Moritz M, Giblin J, Ciccone M, Davis A, Fuhrman J, Kimiaie M, Madzsar S, Olson K, Senn M (2011) Social risk-management strategies in pastoral systems: a qualitative comparative analysis. Cross-Cult Res 45(3):286-317. doi:10.1177/1069397111402464

Munzbergova Z, Ward D (2002) Acacia trees as keystone species in Negev desert ecosystems. J Veg Sci 13 (2):227-236. doi:10.1111/j.1654-1103.2002.tb02043.x

Näser C (2012) Nomads at the Nile: towards an archaelogy of interaction. In: Barnard H, Duistermaat K (eds) The history of the peoples of the Eastern Desert. Cotsen Institute of Archaeology, Los Angeles, pp 81-89

Niamir-Fuller M (1999) Managing mobility in African rangelands: the legitimization on transhumance. FAO, Rome

Pierce RH (2012) A Blemmy by any other name...: a study in Greek Ethnography. In: Barnard H, Duistermaat K (eds) The history of the peoples of the Eastern Desert. Cotsen Institute of Archaeology, Los Angeles, pp 226-237

Rackham O (1976) Trees and woodland in the British landscape., Archaeology in the field seriesJ.M. Dent, London

Reynolds JF, Smith DMS, Lambin EF, Turner BL II, Mortimore M, Batterbury SPJ, Downing TE, Dowlatabadi H, Fernandez RJ, Herrick JE, Huber-Sannwald E, Jiang H, Leemans R, Lynam T, Maestre FT, Ayarza M, Walker B (2007) Global desertification: building a science for dryland development. Science 316(5826):847-851. doi:10.1126/science.1131634

Riad M (1974) Cultural regions in south-eastern Egypt. In: Weheba A-F, Riad M, Seteha M (eds) South-east Egypt (Geographical Essays). Beirut Arab University, Beirut, pp 27-51

Roper EM (1928) Tu Bedawie. An elementary handbook for the use of Sudan government officials. Stephen, Austin 
Rowe A (2006) Conservation, land and nomadic pastoralism: seeking solutions in the Wadi Araba of Jordan. In: Chatty D (ed) Nomadic societies in the Middle East and North Africa: entering the 21st century. Brill, Leiden, p 795

Salzman PC (1972) Multi-resource Nomadism in Iranian Baluchistan. J Asian Afr Stud 7(1-2):60-68. doi: $10.1177 / 002190967200700105$

Sauer C (1925) The morphology of landscape. Univ California Publ Geogr 2(2):19-53

Schlüter O (1907) Über das Verhältnis von Natur und Mensch in der Anthropogeographie. Geographische Zeitschrift 13:505-517

Stewart FH (2006) Customary law among the Bedouin of the Middle East and North Africa. In: Chatty D (ed) Nomadic societies in the Middle East and North Africa: entering the 21st century. Brill, Leiden, pp 239-279

Thomas DSG, Middleton NJ (1994) Desertification: exploding the myth. Wiley, Chichester

UNESCO Cultural Landscape. http://whc.unesco.org/en/culturallandscape/\#1. Accessed Jan 2014

Vetter S (2005) Rangelands at equilibrium and non-equilibrium: recent developments in the debate. J Arid Env 62(2):321-341. doi:10.1016/j.jaridenv.2004.11.015

Vose RS, Schmoyer RL, Steurer PM, Peterson TC, Heim R, Karl TR, Eischeid JK (1992) The Global Historical Climatology Network: Long-term monthly temperature, precipitation, sea level pressure, and station pressure data. Other Information: DN: Environmental Sciences Division Publication No. 3912; PBD: Jul 1992

Wehr H (1976) A dictionary of modern written Arabic Inc. Ithaca, New York

Westoby M, Walker B, Noymeir I (1989) Opportunistic management for rangelands not at equilibrium. J Range Manag 42(4):266-274

Wiegand K, Jeltsch F, Ward D (2004) Minimum recruitment frequency in plants with episodic recruitment. Oecologia 141(2):363-372. doi:10.1007/s00442-003-1439-5

Zahran MA, Willis AJ (2009) The vegetation of Egypt, 2nd edn. Springer, New York 